\title{
Digitális oktatás a család szemszögéből
}

\author{
Bencéné Fekete Andrea \\ Magyar Agrár-és Élettudományi Egyetem Kaposvári Campus Neveléstudományi Intézet \\ Gyermeknevelési Tanszék
}

\begin{abstract}
Absztrakt
A Covid19-vírus pillanatok alatt alakította át életünket és változtatta meg az iskolák és családok hétköznapjait. A pedagógusoknak egyik napról a másikra kellett átállniuk a digitális oktatásra, ezzel egy időben sok olyan fórum indult el, ahol a résztvevők módszertani segítséget nyújtottak egymásnak, és összegyüjtötték a rendelkezésre álló eszközöket. Egymást tanítva, a tudásmegosztás és egy új kapcsolattartási forma segítségével hazánkban is elindult az online oktatás. Ez az időszak a szülőket is kihívás elé állította, mert új kompetenciákat kellett elsajátítaniuk annak érdekében, hogy segíteni tudják gyermekeiket az online tanulási térben. A jelenlegi, nem reprezentatív feltáró kutatás célja annak vizsgálata volt, hogy miként alkalmazkodtak az alsó tagozatos gyerekek szülei $(\mathrm{N}=113)$ ahhoz, hogy váratlanul új szerepbe kerültek, sok esetben tanítókká váltak munkájuk mellett, otthoni környezetükben. A vizsgálat fókuszában a digitális iskola első periódusa áll, mégpedig a szülők szemszögéből. A kutatás keretében vizsgáltuk, milyen eszközöket, felületeket alkalmaztak a pedagógusok az online tanulás során. Bemutatásra kerülnek a pedagógus-szülö-gyermek kapcsolattartási formák, valamint a tanulásirányítás, tanulástámogatás módjai. A kutatás segítségével a szülők szemszögéből nyerhettünk betekintést a digitális iskola első pár hónapjába. Összességében elmondható, hogy a szülők megítélése szerint a gyerekek sikeresen teljesítették a számukra kitűzött feladatokat.
\end{abstract}

Kulcsszavak: tantermen kívüli digitális oktatás, szülők szerepe, digitális kompetencia

Napjainkban a munka világában és a magánéletben is teret hódítottak az online eszközök, szinte elképzelhetetlenek hétköznapjaink okostelefon, laptop és internet nélkül. Az életterünk és az iskola világa is átkerült a virtuális térbe.

Digitális oktatás alatt az információs és kommunikációs technológiai eszközökkel támogatott tanulást és tanítást értjük; minden olyan, a tanítás-tanulás folyamatában alkalmazott eszköz használatát, amellyel gyorsan és hatékonyan át lehet adni az új ismereteket, valamint amely segíti a gyors információfeldolgozást. Ez az oktatási forma történhet hagyományosan, tantermi keretek között, illetve tantermen kívül, az online térben.

A digitális oktatás feltétele a megfelelő eszközök mellett a pedagógiai módszertani paradigmaváltás. A 21. században megjelent a „digitális szülo"” fogalma, amely arra hívta fel a figyelmet, hogy a szülőknek is kell rendel- 
kezniük digitális kompetenciával, hogy a gyerekekkel lépést tudjanak tartani (Sárkány, 2019). Az online iskola a tantermi oktatás elemeiből is merített, ahol már korábban is alkalmaztak IKT-eszközöket, számítógépet, okostelefont, tabletet, de jelenleg az online felületen, virtuális osztályteremben, digitális együttműködés formájában kerül sor az óra megtartására. Ez a lehetőség azonban nem szigorúan a tantárgy tervezett tanítására alkalmas, hanem a tanuló önirányításának is teret ad (Hargitai et al., 2020).

Az online oktatási környezet összefoglalva a tanulásmódszertant, a technológiai eszközrendszert és a tanulási- és pedagógiai paradigmákat fedi le (Papp-Danka, 2011). A virtuális térben történő tanuláshoz további fogalmak kapcsolódnak. Az e-learninget sok helyen, sokféleképpen értelmezik, egységes meghatározása nincs. Benedek András könyvében már 2013-ban olvasható, hogy az e-learning webalapú, interneten keresztül történő távoktatást jelentet. A tágabb értelmezés, megegyezik az Európai Unió által elfogadott meghatározással, mely szerint korszerü multimédia-technológiák és internet alkalmazását jelenti, mely segíti az oktatás minőségének javítását, biztosítva a forrásokhoz való könnyebb hozzáférést, az információcserét és az együttmüködést (Benedek, 2013).

A digitális környezet a társadalmi kommunikáció és az integráció új formája, amely nem csak hatékony infokommunikációs eszközök alkalmazását jelenti, hanem digitális közegre épülő új társadalomszerveződést, hálózati kultúrát, amely ma már meghatározza mindennapjainkat. A digitális médiumok rugalmasabban és sokszínűbben teszik lehetővé az információk közvetítését (Jakab, 2020). A vegyes típusú oktatást az online iskolát megelőző időszakban is már alkalmazták, elsősorban a felnőttoktatásban (Benedek, 2013).

A blended learning a hagyományos, jelenléti oktatást és a távoktatás elektronikus tanulási környezetét és tananyagát ötvözi, ahol kooperatív technikák alkalmazásával, változatos módszerekkel, egyéni képességeket figyelembe véve történik a tanítás-tanulás (Forgó \& Komló, 2021). Egyidejüleg van jelen az irányított és az önszabályozó tanulás, a szinkron kommunikáció vegyül az aszinkron kommunikációval. A szinkron kommunikáció esetében egy időben csatlakozik a két fél a kommunikációs csatornához, míg az aszinkron kommunikációnál az üzenetet a másik fél később kapja meg (Papp-Danka, 2014).

Ebben a tanulási modellben is fontos szerepet kap a személyes kontaktus, az órák megadott helyén és idején való személyes részvétel, s az online tér tanulástámogató felületein keresztül a diákok szintén kapcsolatba léphetnek a tanárokkal és egymással is. A diákok az önálló munka során a tananyaghoz kötődően készíthetnek projektfeladatokat, podcastokat, blogokat, vlogokat, határidős beadandókat, így az online térben történő tanulás kiválóan alkalmas a kreativitás fejlesztésére is. Loveless $(2002,2007)$ szerint (idézi Bereczki, 2019), a digitális eszközök fokozhatják a kreatív tanulási folyamat hatékonyságát, a képi, videó- és hangfelvevő, lejátszó eszközök alkalmazása során a tanulók ötleteket kaphatnak, kipróbálhatják gondolataikat, tesztelhetik feltevéseiket a tananyaghoz kapcsolódóan. Digitális tartalmakat, animációkat, 
videókat, prezentációkat, blogbejegyzéseket készíthetnek a felhasználók. A kommunikációs technológiák alkalmazása - chat, e-mail, és videó konferencia - segítik az együttmüködést, ösztönzik a közös munkát. A digitális eszközökkel megvalósítható az objektív értékelés is, mert a tanulók szélesebb körben oszthatják meg munkájukat, ötleteiket és kaphatnak visszajelzést. Az új felületek, új módszerek számos lehetőséget kínálnak arra, hogy hatékonyabb, és a mai fiatal generáció számára érdekesebb legyen a tanulás.

A hirtelen váltás azonban nem bizonyult könnyü feladatnak. A tantermen kívüli digitális oktatás egyik napról a másikra váratlan kihívást jelentett a tanítás-tanulási folyamat résztvevői számára, és új elvárást támasztott a szülőkkel szemben is, akik a gyerekeik tanulási tevékenységének jóval aktívabb részeseivé váltak.

\section{Digitális szülők, tanárok, diákok}

Több kutatás bemutatta, hogy a digitális környezet milyen lehetőségeket nyújt a kisgyermekek számára (Lénárd, 2019), az IKT eszközök alkalmazásának lehetőségeit óvodás korban (Németh et al., 2020), milyen lehetőségek rejlenek a digitális környezetben müködő iskolában (Jakab, 2020), milyen szerepe van a pedagógusnak a digitális társadalomban (Buda, 2017), és hogyan fejleszthető a kreativitás a digitális eszközökkel támogatott tanulás környezetben (Bereczki, 2019). Az elmúlt hónapokban a kutatók arról kérdezték a pedagógusokat, hogy milyen tapasztalatokat szereztek (Malatyinszki, 2020), hogyan szervezték meg a digitális átállást, és hogyan müködött a virtuális tanterem (Thékes, 2020). Fekete Mariann (2020) a digitális átállás első heteinek hazai tapasztalatait tárta fel, szentimentanalízis segítségével, és rámutatott az online tanításhoz kapcsolódó módszertani, szakmai nehézségekre,, a problémákra, az IT ismeretek és a digitális tananyagok hiányára (Fekete, 2020).

Egy kutatócsoport vizsgálta az otthoni tanulás sikerességét bejósló tényezőket az eltérő szociokulturális háttérrel rendelkező családok esetében (Szilveszter et al., 2021), valamint a Covid19 hatására bekövetkezett változásokat a családok életében, az időgazdálkodásban történt változást, az otthoni tanulás új módszereit és a digitális átállás által okozott nehézségeket (Engler et al., 2021).

A tanulás az online térben is társas tevékenységként valósul meg, hiszen ugyanolyan mértékben jönnek létre a kapcsolatok, csupán közvetett módon. A társas tanulás ember-gép-ember interakcióval történik, mely során a téridő rugalmas kezelése lehetővé teszi a tanulók egyéni képességeit figyelembe vevő fejlesztést (Benedek, 2013). Korábban a távoktatási formát elsősorban a felnőttoktatásban, esetleg a felsőoktatásban alkalmazták, a közoktatásban nem volt hagyománya (Malatyinszki, 2020).

A digitális tanulás a tanárok és diákok esetén hol azonos, hol különböző digitális kompetenciákat követel meg. A különbségek a tanulási célokban és 
a mérési-értékelési követelmények kidolgozásában nyilvánulnak meg, mert ezek a pedagógus kompetenciájához kapcsolódnak. Mindegyik félnek nyitottnak kell azonban lenni az új befogadására, és elkötelezettnek a tanítás-tanulás iránt. Rengeteg új lehetőség rejlik az online tanulásban, és sok élményt biztosít a játékra alapozott ismeretszerzés is (Benedek, 2013).

Az átalakulás folyamata magában rejti az oktatás tárgyának, tartalmának és módszereinek változását. Csépe Valéria és Török András az okoseszközök oktatásban történő alkalmazásának lehetőségeit, előnyeit és veszélyeit vizsgálták, elsősorban kognitív, idegtudományi szempontból (Csépe \& Török, 2020).

A digitális térben történő tanulás során minden résztvevő szerepköre megváltozott. Alapvetően a pedagógus nem a tudás egyetlen birtokosa, hanem, a tanítás-tanulási folyamat irányítója, segítője; és ennek a támogató szerepkörnek a jelentősége a digitális oktatás során látványosan megnövekedett. A diákoknak is új elvárásoknak kell megfelelniük, a digitális világhoz füződő hozzáállásuk átalakult az online iskolának köszönhetően, most már nem csak a szórakozást, játékot jelentik számukra a digitális eszközök.

Az új kihívások azonban váratlanul érték az oktatás minden résztvevőjét, hiszen az NAT-ban nem szerepel első osztálytól a digitális kompetencia fejlesztése és a szülők sem biztos, hogy a digitális iskola elvárásainak megfelelő informatikai tudással rendelkeztek ahhoz, hogy gyermekeiknek segíteni tudjanak. A pedagógusok is nehézségekkel küzdöttek, ezt igazolja egy 2021-es, pedagógusok körében végzett nem reprezentatív kutatás (Páli, 2021), mely szerint a válaszadók $(\mathrm{N}=139)$ többsége - az informatikatanárok kivételével - minimális informatikai tudással rendelkezett az online oktatás kezdetén, ezt követően legtöbben autodidakta módon fejlesztették digitális kompetenciáikat. A megkérdezett pedagógusok úgy gondolták, hogy közepesen tudták csak átadni az új ismereteket a tanulóknak, és csak a létfontosságú problémákra születtek megoldások a tantermen kívüli digitális oktatás idején. A pedagógusok számára nem elegendő az, ha megfelelő digitális kompetenciával rendelkeznek, mert még szükségük van didaktikai és módszertani tudásra, ismeretre, annak érdekében, hogy a tanítás-tanulás folyamatában eredményesen, a gyerekek számára érdekesen tudják alkalmazni a digitális eszközök által nyújtott lehetőségeket (Turzó-Sovák, 2020).

Az online iskolában átalakultak a gyerekek feladatai is, hiszen a tanulási stílusok, módszerek is folyamatos változáson mentek keresztül a digitális környezethez való alkalmazkodás során. A mai gyermekekre jellemző, hogy egyre felületesebben olvasnak, ugyanakkor egy időben, párhuzamosan több feladatot is képesek elvégezni, multitaskingolnak. Gyorsan dolgoznak, ezt várják el másoktól is, a válaszokat és a visszajelzéseket is azonnal igénylik. Érdeklődők, információt keresnek a világhálón, böngésznek, a kíváncsiság vezérli őket, de inkább a képi, videó- és hangalapú anyagokat részesítik előnyben, nem a szöveget, amelyet olvasni kell. Ügyesen használják a szociális média által biztosított kommunikációs lehetőségeket (Sárkány, 2019). 
Ezekre a változásokra azonban nemcsak szülőként érdemes jobban odafigyelni, hanem az oktatási módszereknek is át kell alakulniuk, amennyiben a pedagógusok szeretnék fenntartani a digitális nemzedék figyelmét. A mai gyerekeket ugyanis egyre kevésbé köti le a szöveges, offline tananyag, ezért az iskola idővel az unalom és a motiválatlanság forrásává válhat. Nem egyszerü feladat azonban a digitális tanulás/oktatás határait megszabni, hiszen a számítógép alkalmazásának nagyon sok előnye van, de számos veszélyt is rejt. A digitális eszközökkel történő tanulás fejleszti a digitális szövegértést (Racskó, 2017), a digitális kompetenciát (Lénárd, 2019), de a virtuális világban történő önálló barangolás veszélyt is jelenthet a tanulók számára (Engler, 2020).

Malatyinszki Szilárd (2020) a pedagógusok szemszögéből (N=315) vizsgálta meg a digitális oktatás eredményeit, tapasztalatait. A megkérdezett pedagógusok 90\%-a rendelkezett a megfelelő eszközökkel, de 15\%-uk egyáltalán nem vett részt korábban semmilyen oktatáson, ahol a digitális eszközök alkalmazását elsajátíthatta volna. A válaszadó pedagógusok 72,1 \%-a közel érezte magát a digitális oktatáshoz, de nincs 10\% azoknak az aránya, akik úgy vélekedtek, hogy az általuk oktatott tantárgyak teljes mértékben digitális módon is oktathatók.

A pedagógusok véleménye szerint a tanulóknak a legnagyobb nehézséget az időgazdálkodás és a tanulásmódszertani hiányosságok okozták. Úgy vélik a megkérdezettek, hogy a tanulók több mint 50\%-a készségszinten tudja alkalmazni az eszközöket, és nem jelent gondot számukra az oktatási tartalmak kikeresése. A tanulók 42,2\%-ánál azonban sok hiányosságot véltek felfedezni, 7\% pedig egyáltalán nem készült fel a digitális oktatásra.

Thékes István (2020) a karaténiskola első két hetét követően kérdezte meg az iskolaigazgatókat $(\mathrm{N}=44)$ az első tapasztalataikról és a rájuk váró feladatok megvalósításának lehetőségeiről, terveiről. Az intézményvezetők irányításával a pedagógusok egy hétvége alatt próbáltak megismerkedni azokkal a felületekkel, amelyeket alkalmasnak találtak az online oktatásra. Legtöbben a Google Classroom (63,6\%) mellett döntöttek, az üzeneteket pedig a Kréta rendszeren keresztült küldték a szülőknek és a gyerekeknek (79,5\%). Ezen kívül elsősorban Facebook zárt csoporton keresztül tartották a kapcsolatot, mivel a szülők és a gyerekek ezt a platformot ismerték a legjobban. A digitális tananyagok megosztására leginkább alkalmazott felületek az Okosdoboz (81,4\%), Mozaweb $(72,1 \%)$ és a Learning Apps $(72,1 \%)$ voltak. A számonkérésre elsősorban a Redmenta (56,4\%) felületét találták alkalmasnak. Az online órákat a Skype $(59,5 \%)$ és a Zoom $(52,4 \%)$ felületén tartotta a megkérdezett igazgatók véleménye szerint a pedagógusok többsége. A kutatás szerint a szülők nem élték meg reménytelenül negatívan a változást, mert csak 9,1\%-uk találta rendkívül negatívnak az online oktatásra történő átállást (Thékes, 2020). 


\section{A szülői tapasztalatok vizsgálata a hazai és nemzetközi kutatásokban}

A karantén során kialakult helyzetet a kutatók, mint fent is látható, sok szempontból vizsgálták, de kevés tanulmány elemezte a helyzetet a család szemszögéből. A digitális iskolában a szülők a pedagógusok munkatársává váltak, vagy mint "tanulótársak” jelentek meg, akik segítettek, vagy együtt tanultak a gyerekeikkel. A tantermi oktatás során a szülői szerepkör elsősorban a törődésben, kikérdezésben valósult meg, amelynek nem volt feltétele az IKTháttér és a digitális kompetencia. A Kopp Mária Intézet a Népesedésért és Családokért (KINCS) reprezentatív kutatást végzett $(\mathrm{N}=1000) 2020$ áprilisában, melynek célja a családok helyzetének feltárása volt a karantén idején. A minta a magyar lakosságot tekintve nemre, életkorra, iskolai végzettségre és településtípusra volt reprezentatív. A kutatás középpontjában nem a távolléti oktatás állt, de sok részletét felderítette. A válaszadók 51\%-a egyetértett azzal a döntéssel, hogy az iskolák átálltak a digitális oktatásra (Engler, 2020).

A megkérdezettek 42\%-a, 422 fő nevelt otthonában gyermekeket, így az oktatáshoz kapcsolódóan az eredmények csak az ő válaszaikat tartalmazzák. A kutatás arra kereste a választ, hogy a különböző tevékenységek a családok számára mennyire okoztak nehézséget a karantén idején. A legnagyobb problémák egzisztenciális és egészségügyi irányultságúak voltak. Egzisztenciális jellegű nehézséget jelentett a munkahely és az anyagi biztonytalanság, valamint az egészségügyi ellátás. A családosok esetében az otthoni munka és a gyerekekkel történő tanulás, a család és a munka összeegyeztetése, a család ellátása, az otthoni tanulás támogatása, és a gyermekek felügyelete okozta a legnagyobb nehézséget. A gyermekeket nevelők véleménye szerint ( $\mathrm{N}=422)$, az átlagértékek alapján felállított nehézségi rangsorban 1. a munkahelyi bizonytalanság, 2 . a pénz előteremtése és beosztása, a 3. várandós ellátás, a 4. aaz otthonról történő tanulás segítése, illetve az 5 . legnagyobb nehézség a család eltartása.. Minél magasabb volt a gyermekek száma a családban, annál nagyobb nehézséget jelentett a tanulás megoldása a szülők számára (Engler, 2020).

A kutatók arról is érdeklődtek, hogy milyen segítséget igényelnének a családok az otthoni tanuláshoz. A megkérdezettek mindössze egy tizede kérne támogatást, elsősorban a kisebb városokban, falvakban élők, akik négy vagy több gyermeket nevelnek. A házi feladat ellenőrzésében, illetve gyakorlás során biztosított támogatást a válaszadók $9 \%$-a rendszeresen, $13 \%$-a gyakran és 16\%-a ritkán kérne. $62 \%$ azonban egyáltalán nem igényel támogatást, ezek a szülők többségében nők, alacsonyan iskolázottak, kistelepülésen, kedvezőtlen anyagi körülmények közt élnek, a harmincas éveikben járnak. Gyermekeikkel a megkérdezettek több mint a fele tanul rendszeresen, közülük azok a szülők felülreprezentáltak, akik nem kértek egyáltalán segítséget az otthoni tanuláshoz. Feltehetően, akik rendszeresen részesei voltak korábban is a gyermekeik tanulási folyamatának, ismerik a megfelelő módszereket is. 
A kutatás eredményei arra is rávilágítottak, hogy az összezárt családokban jelentősen nőtt a közös étkezések, szabadidős tevékenységek száma, és a házimunkából is mindenki kivette a részét. A családok fontosnak tartották a tanulmányok nyomon követését, de nem ez állt a középpontban.

A Covid19 átalakította a családok hétköznapjait. A közös tanulás a megkérdezettek 40\%-ánál vált gyakoribbá, mint a karantén előtti időszakban. Az alsó tagozatos gyermekekkel foglalkoztak jelentősen többet a szüleik, míg az életkor elörehaladtával ez csökkenést mutatott (Engler, 2020).

Malatyinszki Szilárd (2020) két héttel a digitális oktatás kezdetét követően kérdezte meg a szülőket $(\mathrm{N}=900)$. A kitöltők 90,4\%-a nő volt, a felsőfokú végzettséggel rendelkezők voltak felülreprezentáltak. A szülők 40\%-a 0-2 órát, 30\%-a 2-3 óra, 20\% 3-5 óra közötti időt töltött gyerekével együtt tanulással. A megkérdezettek 9\%-a naponta több, mint 5 órát tanult gyermekével. A kutatási eredmények arra világítottak rá, hogy a szülőktől nagy energiabefektetést kívánt a gyerekekkel történő tanulás a munka és a háztartás vezetése mellett. Legnagyobb nehézséget a családoknak az általános iskolásokkal, főként az alsó tagozatos gyermekekkel történő tanulás okozott (Malatyinszki, 2020).

A hátrányos helyzetű családok számára különösen nagy kihívást jelentett az otthoni, önálló tanulás, Szilveszter Áron és munkatársai által 2020 tavaszán készült kutatás (2021) arra kereste a választ, hogy a szocioökonómiai státusz, a háztartási rendezettség, a családi rutin, és a gyerekek tanulásba fektetett erőfeszítése közül melyik tényezők jelzik előre a tanulás sikerességét. A kutatók az eredmények alapján arra a következtetésre jutottak, hogy nem a szülők magas iskolai végzettsége, anyagi helyzete volt meghatározó a tanulás sikerességében a digitális oktatás idején, sokkal inkább a megfelelő adaptáció volt meghatározó. A családok részéről nagyfokú rugalmasságot igényelt az új szokásrendszer kialakítása, mely hatással volt a gyermekek tanulásba fektetett erőfeszítésének mértékére, illetve motivációjuk fenntartására (Szilágyi et al, 2021).

Engler Âgnes és munkatársai (2021) is arra a következtetésre jutottak, hogy nem a szülők kvalifikáltsága a befolyásoló tényező, mert minden szülő igyekezett a legtöbbet segíteni gyermekének a tanulásban. A szülők munkavégzésének módja és a gyermekek száma viszont befolyásolta a közös tanulás mennyiségi mutatóit (Engler et al. 2021).

Brom és munkatársai (2020) Csehországban vizsgálták az 1-9. osztályos gyermekek szüleinek tapasztalatait az online oktatás idején. Kutatási eredményeik szerint a cseh családok alapvetően jól birkóztak meg a digitális oktatás állította kihívásokkal, és az online oktatást pozitív élményként fogták fel. A cseh gyermekek általában napi 2- 4 órát töltöttek tanulással, ennek felét szülői segítséggel, amely elsődlegesen a feladatok értelmezésében és ellenőrzésében nyilvánult meg. Esetükben a leggyakrabban a technikai feltételek, valamint a megfelelö pedagógiai vagy tantárgyi tudás merült föl, mint probléma, illetve sokaknál nem állt rendelkezésre megfelelő mennyiségü 
idő a gyermekekkel való tanulásra. Brom és munkatársai (2020), valamint Simonsen és munkatársai (2020) kihangsúlyozták, hogy fontos, hogy a pedagógusok ne csak feladatokat adjanak, hanem lehetőséget biztosítanak az interaktív online tanulásra is (Brom et al., 2020; Simonsen et al., 2020). A fenti kutatások arra mutattak rá, hogy Magyarországon és Csehországban is volt számos nehézség, de a családok ennek ellenére összességében sikeresen birkóztak meg az online oktatás kihívásaival. Nem minden országban volt azonban a szülők szemszögéből pozitív a digitális oktatás helyzete.

Kínában jelentősen negatívabb volt a szülők vélekedése, ők a hagyományos oktatást preferálták. Ellenállásuknak három fö oka volt: az online oktatás sokszor kevésbé hatékony, a gyermekeknek pedig, főleg fiatalabb korban nincs meg a kellő önfegyelme az önálló tanuláshoz, miközben a szülők a szükséges szaktudással nem rendelkeznek ahhoz, hogy gyermekeik tanítói legyenek (Chuanmei et al., 2020). Indiában is 2020. áprilisában fokozatosan vezették be az online oktatásat.

Grover és munkatársai (2021) Indiában, 2020. június 21 és július 17 között végzetek egy kutatást, mely során a 289 gyermek gondviselőjét kérdezték meg. A tanulók 93,8\%-a angol nyelvü magániskolában tanult. A válaszadók $67,8 \%$ nő volt, átlagéletkoruk 37,2 év, 67,5\%-uk diplomával rendelkezik, 75,4\%-uk városban él. A gondviselők 81,7\%-a szerint az online oktatás kevésbé kényelmes, 78,5\% szerint pedig kevésbé kielégítő, mint a hagyományos. A gondviselők 80,6\%-a számolt be arról, hogy a gyermekek figyelme és koncentrációja nem volt megfelelö, $82,4 \%$ pedig úgy látta, hogy mind a gyakorlati, mind az elméleti tudás átadása sérült az online oktatás során. 52,2\% szerint a legnagyobb problémát az interneten való szörfözés és játék jelentette a tanórák alatt, de felmerült problémaként a növekedett stressz, a bezártság és a személyes higiéniára való igény csökkenése is (Grover et al., 2021).

Cakin és Külekci Aykavuz (2021) Törökországban, kvalitatív kutatás keretében vizsgálták általános iskolában tanuló gyermekek szüleinek véleményét 2020. júniusában az online oktatásról. A húsz válaszadó életkora 28 és 50 év között oszlik meg, közülük 11 anyuka és 9 apuka, akiknek iskolai végzettsége teljesen eltérő. A kutatásból kiderült, hogy a török szülők nem tartják megfelelőnek az online oktatást az ismeretek átadására; mivel a földrajzi, anyagi és technológiai lehetőségek nagyon eltérőek lehetnek, az egyes tanulók hátrányba kerülhetnek. Brom és munkatársai (2020), Chuanmei és munkatársai (2020) és Grover és munkatársai (2021) által publikált kutatási eredményekhez hasonlóan ez esetben is kiemelt szerephez jutott a szülők képzettségének hiánya az egyes tantárgyakat illetően, de kihangsúlyozták a tanárok általi támogatás hiányát, valamint a tananyag nehéz elérhetőségét is (Cakin \& Ayvuz, 2021). A fentiekben bemutatott hazai és nemzetközi kutatások is arra utalnak, hogy a szülők az online iskola aktív szereplőjévé váltak, azonban az első iskolabezárásokat követően létrejött digitális iskolát még nem tartották elég hatékonynak. Külföldön is és hazánkban is nagy kihívás elé állította a szülők az új tanulástámogató szerep. 
Saját kutatásunkban Magyarországon élő, az általános iskola alsó tagozatán tanuló gyerekek szüleit kérdeztük meg a tantermen kívüli oktatás során szerzett tapasztalataikról.

\section{A kutatás célja, kérdései}

A jelenlegi, nem reprezentatív, feltáró kutatás célja annak vizsgálata volt, hogy miként alkalmazkodtak az alsó tagozatos gyerekek szülei az online oktatás új elvárásaihoz. Váratlanul szokatlan szerepbe kerültek, sok esetben át kellett venniük a pedagógusok feladatát otthoni környezetükben. A kérdőív online felületen készült, mely tartalmazott zárt és rövid szöveges válaszokat igénylő nyitott kérdéseket egyaránt.

A kutatási kérdések arra irányultak, hogy:

- Milyen eszközöket, milyen felületeket alkalmaztak a pedagógusok az online tanulás során? Ismerték-e már korábban és alkalmazták-e már ezeket a platformokat?

- Milyen módszerekkel tartották a kapcsolatot a tanulókkal és a szülőkkel, és hogyan irányították az otthoni tanulást?

- Mely tantárgyak esetében volt valós idejű online óra?

- Milyen mértékben okozott nehézséget a feladatok megoldása és az új ismeretek megtanulása? Igényelték-e és kaptak-e a szülők módszertani tanácsot a tanuláshoz, a napirend kialakításához és a szabadidő eltöltéséhez?

- Hogyan értékelték a szülők a kapcsolattartás minőségét, illetve gyermekeik tanulási teljesítményét?

\section{Adatgyüjtés, az elemzés módszerei}

Az adatfelvételre 2020 júniusában került sor online felületen, önkényes mintavétellel. A kitöltőket írásban tájékoztattuk a kutatás céljáról és folyamatáról. A kérdőív kitöltése 25-30 percet vett igénybe, a válaszadás önkéntes és anonim volt. Az alsó tagozatos gyerekek szüleitől 113 értékelhető kérdőív érkezett vissza. Az elemzések SPSS szoftver segítségével, leíró statisztikai számításokkal készültek, a kódolás Microsoft Excel programmal történt. A kutatás segítségével a digitális iskola 2020-as tavaszi hónapjai tárulnak fel a szülők szemszögéből.

\section{A kutatás mintája}

A kutatási kérdésekre 113 fó válaszolt. A kutatásban önkéntesen résztvevő, alsó tagozatos gyermekek tanulását segítő személyek 92\%-a nő, 8\%-a férfi. A kérdőív kitöltésére elsősorban az anyák (84\%) vállalkoztak, feltehetően az ő feladataik közé tartozott elsősorban a gyerekek tanulásának támogatása a digitális oktatás idején. A válaszadók között találhatók még apák (5\%), a fennmaradó 11\%-ot pedig nagymamák, nagypapák, idősebb testvérek, egyéb rokonok és ismerősök alkotják. 
A kitöltők életkorát tekintve a legtöbb válaszadó 31-40 év (50\%) és 41-50 év (34,5\%) közötti felnőtt. A válaszadók 9\%-a 20-30 év közötti fiatal, feltehetően ők az idősebb testvérek, rokonok és ismerősök, valamint az 51-60 év $(2,7 \%)$ között és 60 éves kor feletti (3\%) segítők a nagyszülők, rokonok és ismerősök. A pandémia első hulláma idején az idős emberek javasoltan nem tartózkodhattak az iskolás gyermekek közelében, így nem segíthettek rendszeresen a digitális oktatás során.

A kitöltők legmagasabb iskolai végzettsége: 55,8\%-a diplomával, 36,3\%-a érettségi bizonyítvánnyal rendelkezik, 5,3\% szakmunkásképzőben, 2,7\% általános iskolában fejezte be tanulmányait. (1. ábra) Ez az arány az önkéntes kitöltésből adódik, és abból, hogy az online felületeken a kérdőívek kitöltésére inkább a magasabb iskolai végzettségűek vállalkoznak.

\section{1. ábra}

A válaszadók eloszlása iskolai végzettség szerint $(N=113)$

\section{A szülők legmagasabb iskolai végzettsége}

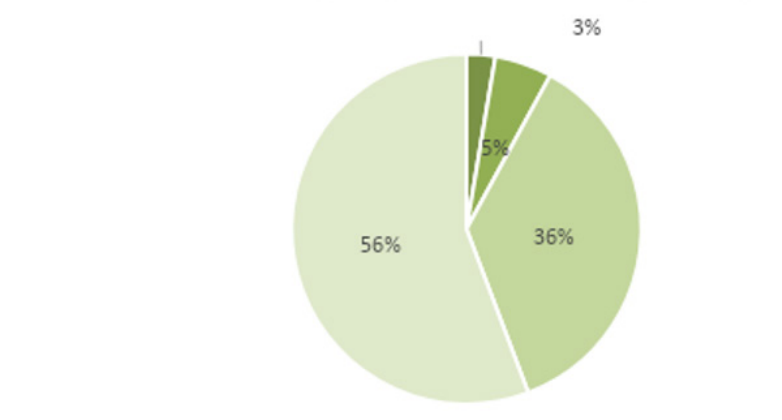

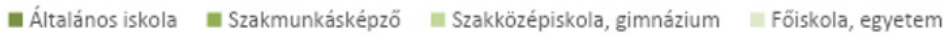

A gyermekek iskolája a legtöbb kitöltő esetében városban (69\%) található, ebből $10 \%$ fővárosi iskolában tanul, a tanulók 30\%-a pedig falusi intézményben. A gyerekek 38,1\%-a faluban él, de közülük 10\% bejár városi, illetve fővárosi iskolába. Az alsó tagozatos osztályok között az eloszlás viszonylag egyenletes, mert a kitöltők 20\%-a első, 28\%-a második, 24\%-a harmadik, 28\%-a negyedik osztályos tanuló tanulását segítette a digitális oktatás idején.

A kutatás során megkérdeztük a szülőket arról, hogy gyermekeikkel milyen eszközöket alkalmaztak az otthoni tanulás során. Ebben az esetben több eszköz megjelölésére is lehetőséget biztosítottunk. Az alábbi, 2. ábrán látható, hogy a kisiskolások leggyakrabban az okostelefont (79\%) és a laptopot (78\%) alkalmazták a tanulás során. 


\section{2. ábra}

Az otthoni tanulás során alkalmazott eszközök $(N=113)$

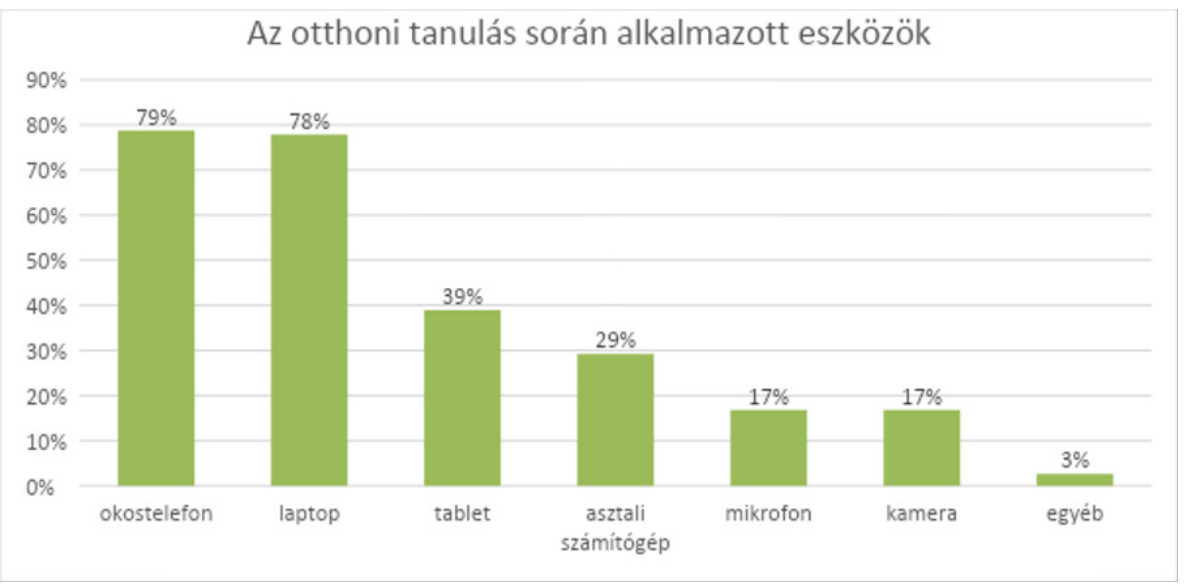

A tanulók 39\%-a tableten, 29\%-a pedig asztali számítógépen dolgozott, melyhez 17\%-uk mikrofont és kamerát használt. A kutatás nem tért ki arra, hogy ezek az eszközök saját tulajdonúak voltak-e, illetve, hogy a gyermek használta-e kizárólagosan a családban, vagy osztoznia kellett rajta a testvérekkel és a szülőkkel. Az egyéb eszközök között megtalálható volt még a fényképezőgép, a nyomtató és a szkenner.

Arra is rákérdeztünk, hogy a digitális oktatás megkezdése előtti tantermi oktatás idején a tanulók milyen eszközöket alkalmaztak az otthoni felkészülés során. A válaszadók 66\%-a szerint gyermeke egyáltalán nem használt IKT-eszközt az otthoni tanulása során, 21\% laptopon, 20\% okostelefonon, $12 \%$ tableten és 5\% asztali számítógépen dolgozott már. Ezek az adatok azt jelentik, hogy nagyon sok tanuló számára újdonság volt az, hogy egyik napról a másikra önállóan kellett tanulnia a digitális eszközök segítségével, annak ellenére, hogy az eszközhasználathoz feltehetően nem rendelkezett megfelelő kompetenciával, hiszen a digitális kultúra tantárgy csak az új, 2020-as Nat szerint tanulmányaikat folytató tanulók számára kerül 3. osztálytól bevezetésre, felmenő rendszerben.

A következő kutatási kérdés arra irányult, hogy az otthoni tanulás során milyen felületeket, illetve milyen célból alkalmaztak az tantermen kívüli digitális oktatás a során a diákok. Az alábbi, 3. ábrán látható, hogy a pedagógussal a kapcsolatot a szülők és a tanulók elsősorban Messengeren (59\%) és Facebookon (45\%) tartották, ez az adat megegyezik Thékes (2020) kutatási eredményeivel; valamint erre a célra alkalmazták még a Google Classroom (19\%), a Zoom (12\%) felületét és néhányan Skype segítségével kommunikáltak. 


\section{3. ábra}

Az otthoni tanulás során a különbözö célokra alkalmazott felületek $(N=113)$

\section{Az otthoni tanulás során különböző célokra alkalmazott} felületek

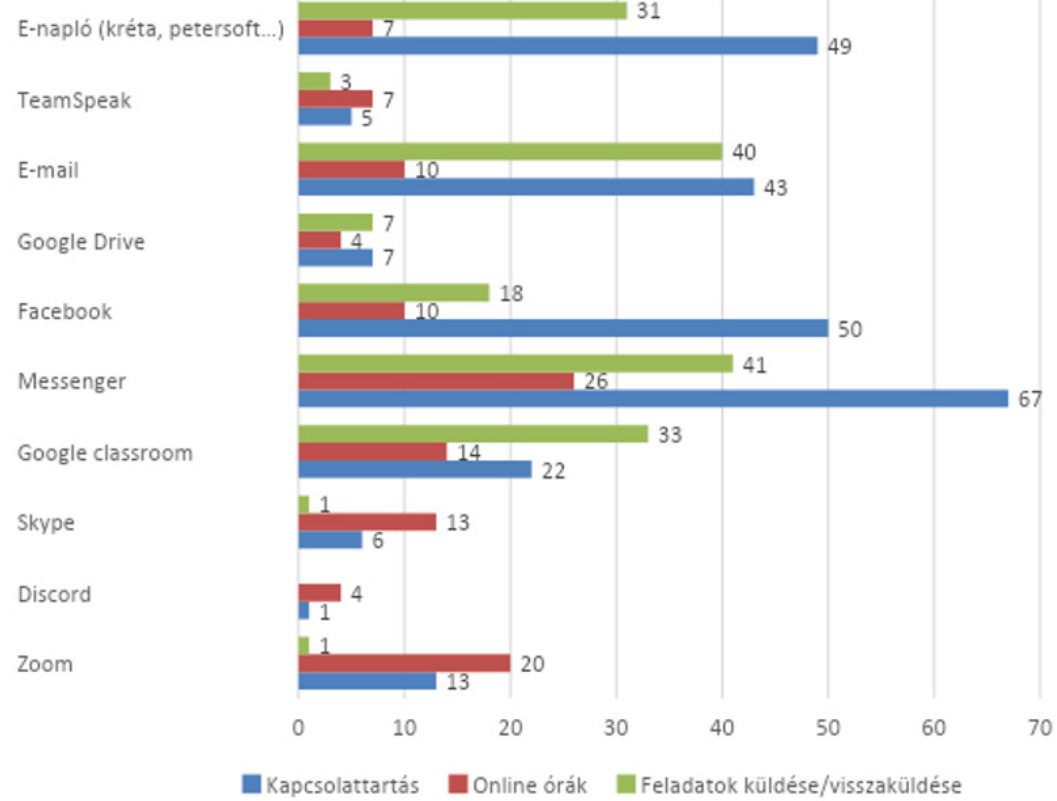

Online órák megtartása a kezdeti időszakban, 2020. március végétől júniusig, még nem volt gyakori, ezt igazolják az általunk megkérdezett szülők válaszai, mert 36\%-uk azt jelezte, hogy egyáltalán nem került sor online órák megtartására egyetlen tantárgyból sem. A szülők 40\%-a írta, hogy a magyar nyelv és irodalom órák esetében volt online óra, 36\%-a szerint matematika órákon is online tanultak a gyerekek. Az idegen nyelv esetében a tanulók 13\%-a, környezetismeret és ének-zene tantárgyak esetében 11\%-a kapott online segítséget tanítójától. Testnevelés esetében a tanulók 7\%-a, vizuális kultúrából 4\%-a, technika és életvitel tantárgyból 2\%-a vett részt online órán.

Ahogy a fenti diagram is mutatja, az online órák megtartása a legtöbb tanuló (23\%) esetében Messengeren keresztül történt, a megkérdezettek 18\%ánál a Zoom felületén, 12\%-ánál Skypon keresztült irányították a pedagógusok a tanítást. Ez az eredmény hasonlít Thékes István (2020) kutatása során kapott adatokhoz, mert ott a szinkron órák megtartására Skypeon (59,5\%) és Zoom (52,4\%) felületen került sor. Az általam megkérdezettek néhány esetben alkalmazták a Facebook (8\%) és a Discord (4\%) felületét is.

A feladatok küldése leggyakrabban Messengeren keresztül történt (41\%), sokan a Google Classroom felületén (12\%) kapták és küldték vissza a felada- 
tokat, de a Facebookot (8\%) is használták erre a célra. Megemlítették még a megkérdezettek, hogy YouTube csatornán keresztül, kisfilmek segítségével gyakorolták a gyerekek a néptáncot, az angol kiejtést, énekórán a dalokat. A természet megismeréséhez is sok segítséget nyújtottak a mesék és a rövidfilmek. A Wordwall, és a Learning Apps felületek játékos gyakorló lehetőséget nyújtottak matematika, nyelvtan, irodalom és idegen nyelv tantárgyakhoz. A Mozaweb felülete feladatok megoldását, tankönyvek használatát tette lehetővé, emellett még különböző weboldalakat alkalmaztak játékos feladatokra.

A valós idejű írásbeli számonkérés jellemzően a Redmenta felületén történt. Sok szülő kiegészítő információként leírta, hogy ezeket a felületeket elsősorban nem a gyerekek használták, hanem a szülők. Önállóan, segítség nélkül nem tudtak a kisiskolás gyerekek megküzdeni a tananyaggal. A fenti eredmények ismételten egyezést mutatnak Thékes (2020) kutatásával, mert az általa megkérdezett igazgatók a Redmentát (56,4\%) említették meg, mint a számonkérés során alkalmazott felületet.

A következő, 4. ábra azt mutatja, hogy a szülők milyen tapasztalatokat szereztek a pedagógusok által alkalmazott tanítási metódusokról.

4. ábra

A távoktatás során a pedagógusok által alkalmazott módszerek $(N=113)$

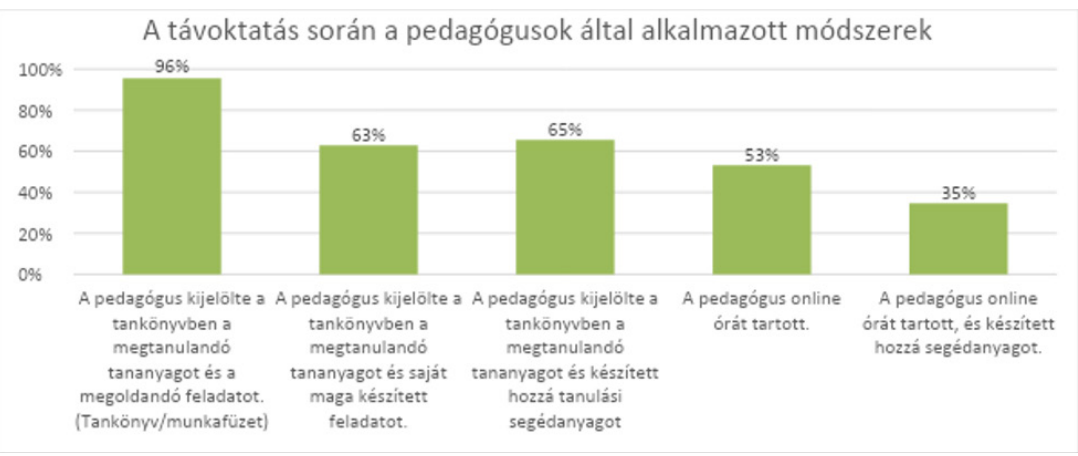

A fenti diagramon látható, hogy mindössze a szülök $53 \%$-a vélekedett úgy, hogy online órákon tanultak a gyerekek. A legtöbb esetben (96\%) a tanulóknak önállóan, illetve szülői segítséggel kellett tanulniuk, a tanító kijelölte a tankönyvben és a munkafüzetben a megtanulandó tananyagot. Ebben az esetben nagyon sok feladat hárult a szülőkre, főként az első és második osztályos tanulók esetében, akik még olvasásból nem biztos, hogy olyan szinten állnak, hogy önállóan tudják értelmezni a feladatokat.

Gyakran előfordult, hogy a tanító kijelölte a tankönyvben a megtanulandó anyagot és önállóan készített hozzá segédanyagot (65\%), vagy kijelölte a megtanulandó anyagot, és saját maga készített hozzá feladatot (63\%). 
Az online órák látogatásának gyakoriságára kérdezett rá a következő kérdés. A válaszok alapján a tanulók $53 \%$-a minden online órán jelen volt, $12 \%$ nyilatkozott úgy, hogy a legtöbb órán ott volt, $4 \%$ az órák felén, $3 \%$ pedig csak néhány órán tudott együtt dolgozni a pedagógusokkal. Az okok között az internetkapcsolat, vagy a gép meghibásodását jelölték meg a szülők, de sok esetben a többgyerekes családoknál a gyerekeknek párhuzamosan mentek az órái és/vagy a szülő nem tudott egyszerre segíteni mindegyiknek, vagy egy gépen kellett osztozni a családnak, illetve azt is megemlítették, hogy a szülőnek kellett dolgozni a gépen munkavégzés céljából.

A korábbiakban említett, KINCS által, 2020 áprilisában végzett reprezentatív „A koronavírus családokra gyakorolt hatása című kutatás $(\mathrm{N}=1000$, ebből $\mathrm{N}=422$ a gyermeket nevelők véleménye) eredményei alapján az első digitális átállás idején a pedagógusokkal való kapcsolattartás a család kommunikációjában háttérbe szorult, a válaszadók 29\%-a egyáltalán nem, 32\%-a pedig csak egyszer-kétszer beszélt a pedagógusokkal az első hónapban.

A kutatás azonban nem tárta fel, hogy melyik félen múlt a kommunikáció gyengesége, de egy korábbi kérdésből egyértelműen kiderült, hogy a pedagógusokkal való kapcsolattartásra nagy volt a szülői igény a távolsági oktatás idején. A szülők 18\%-a rendszeresen szeretett volna beszélni a pedagógusok$\mathrm{kal}$, a $21 \%$-a pedig gyakran élt volna ezzel a lehetőséggel.

Egy következő kérdés arra irányította a figyelmet, hogy a szülők 56\%-a rendszeresen, 22\%-a gyakran érdeklődött gyermekeitől az iskolai történésekről. Ez azt jelenti, hogy a szülők nem voltak érdektelenek, de az információkat nem a pedagógusoktól, hanem a gyerekektől szerezték (Engler, 2020).

Az általunk megkérdezett alsó tagozatos gyermekek szülei esetében kedvezőbb a kép. Az alábbi, 5. ábrán látható, hogy a szülők 45\%-a rendszeresen, naponta tudott beszélni a pedagógussal, $28 \%$-a pedig hetente többször.

\section{5. ábra}

A szülökkel történó kapcsolattartás gyakorisága $(N=113)$

\section{Milyen gyakran tartotta a pedagógus a szülőkkel a kapcsolatot?}

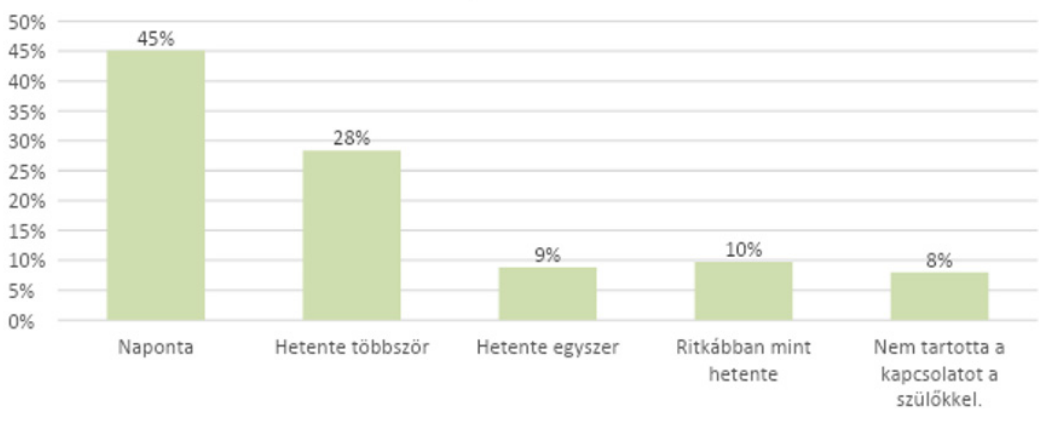


Hetente egy alkalommal a szülők 9\%-a tudott beszélni a pedagógussal, ritkábban, mint hetente a megkérdezettek 10\%-ának volt lehetősége megbeszélni a problémákat gyermekük tanítójával. A megkérdezett szülők 8\%-a mondta azt, hogy egyáltalán nem volt kapcsolata a gyermeke tanítójával.

A tantermi oktatás során az órák végét csengő jelzi, és következik a szünet, az étkezés, délután pedig a játék, a mozgás és a szabadidős tevékenység. Az új helyzetben a gyerekek többnyire a digitális eszköz előtt ültek, és a szülők feladatává vált a gyerekek változatos napirendjének kialakítása, hogy a tanulás mellett jusson megfelelő idő a rendszeres étkezésre, pihenésre és játékra is.

Megkérdeztük a szülőket, hogy kaptak-e tanácsot a pedagógustól a szabadidő eltöltésére, illetve a napirend kialakítására vonatkozóan. Az alábbi, 6 . diagram mutatja, hogy a megkérdezett szülők 52\%-a kapott tanácsot gyermeke szabadidős programjainak tervezéséhez, 52\%-ának nyújtottak segítséget a tanítók a napirend kialakításához, a szülők 21\%-a azonban egyáltalán nem kapott segítséget az iskolától az otthoni életritmus tervezéséhez.

\section{6. ábra}

Szabadidő eltöltésével és a napirend összeállitásával kapcsolatos tanácsok (N=113)

$$
\begin{aligned}
& \text { Kaptak-e tanácsot a pedagógustól a szabadidő } \\
& \text { eltöltésére, illetve a napirend elkészítésére } \\
& \text { vonatkozóan? }
\end{aligned}
$$

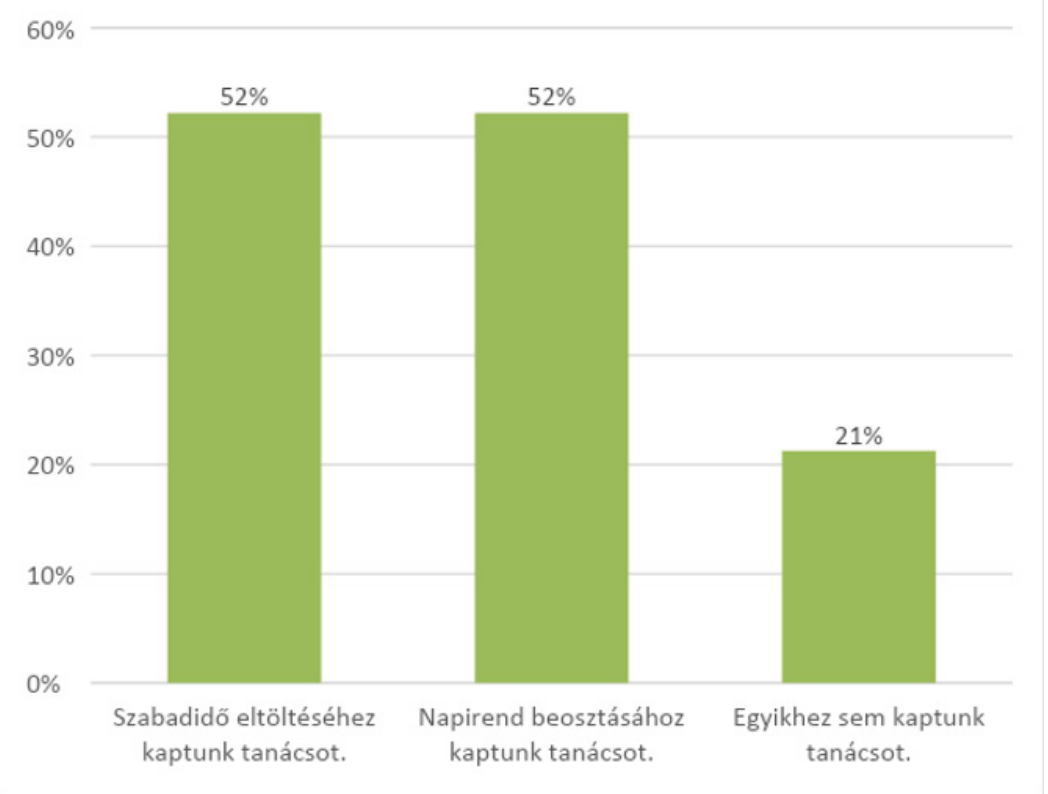


A kutatás során megkérdeztük a szülők véleményét arról, hogy milyen mértékben okozott nehézséget a gyermek otthoni tanulása és a feladatok megoldása. 77\% úgy nyilatkozott, hogy minden tantárgy esetében meg tudták tanulni az új ismereteket, illetve a feladatok megoldása is sikeres volt. A családok 22\%-a érezte úgy, hogy csak néhány esetben küzdöttek nehézségekkel.

A korábban bemutatott KINCS (2021) által végzett kutatás esetében az otthoni tanulás nehézségeinek megítélésében szignifikáns eltérés mutatkozott $(\mathrm{p}=0,005)$ a gyermekek számának függvényében . Minél magasabb a gyermekek száma a családban, annál nagyobb problémát jelentett a szülők számára a tanulás támogatásának megoldása. Érdekes módon a szülők iskolai végzettsége nem volt befolyásoló tényező (Engler, 2020).

A szülők körében folytatott kutatás eredményei alapján ezzel szemben szignifikáns kapcsolat mutatkozott a szülők iskolai végzettsége és a megoldott feladatok aránya között $(\mathrm{p}=0,003)$. A magasabb iskolai végzettséggel rendelkező szülők és gyermekeik nagyobb arányban tudták megoldani a tantermen kívüli oktatás során kapott feladatokat. Az alacsonyabb iskolai végzettséggel rendelkező szülők nyilatkoztak úgy, hogy a feladatok több mint felével egyáltalán nem tudtak megbirkózni. Az általunk végzett kutatás esetében az elemzés során a többi adat összevetése esetében nem fedezhető fel összefüggés. Nem befolyásolta szignifikánsan a tanulók eredményességét sem a megoldott feladatok aránya, sem az órákon való részvétel gyakorisága, sem a pedagógusnak a szülővel való kapcsolattartása, de a megkérdezett családok esetében érdekes módon a pedagógusok által alkalmazott módszerek sem voltak szignifikáns hatással a tanulás sikerességére.

Végül megkérdeztük a szülők véleményét arról, hogy hogyan értékelik a gyermekük tanulási eredményét a tantermen kívüli digitális oktatás idején. Az alsó tagozatos tanulók 58\%-a ugyanúgy teljesített a szüleik szerint, mint általában. Sokkal eredményesebb lett a tanulók 20\%-a, ezzel szemben $20 \%$ uk sokat rontott korábbi eredményén. Összességében véve a megkérdezett szülők véleménye alapján a gyerekek többsége eredményesen vette az akadályokat az online iskolában, de a kutatás arra is felhívja a figyelmet, hogy a nyári pihenést követően kiemelt figyelmet kell fordítani a karantén idején gyengén teljesítő tanulók felzárkóztatására.

\section{A szülőket felkészítő program bemutatása}

A fenti kutatások eredményei arra világítottak rá, hogy a szülők igénylik a segítséget, ahhoz, hogy új szerepükhöz kapcsolódó feladataikat el tudják látni a digitális iskolában, ahol még szorosabb együttműködésre van szükség a család és az iskola között.

Érdemes megfontolni ezért a szülők és a gyermekek számára közös felkészítő program szervezését. Fontos a gyermek jelenléte is, hogy érezze, ő saját maga a felelős tanulásáért, feladatai elvégzéséért, a szülő pedig a segítője ebben a folyamatban. Az első lépés, hogy feltérképezzük, milyen digitális 
eszközök állnak a családok rendelkezésre, illetve milyen módon lehet pótolni vagy helyettesíteni a hiányzó eszközöket. Segítséget nyújthatnak egymásnak a szülők, a családok, ehhez azonban szükségük van egymás gyors elérésére, egy olyan kommunikációs csatorna müködtetésére, ahol a valós információ mindenkihez eljuthat. Így a pedagógus válláról az együttműködő közösség kicsit leveheti a terhet.

A gyerekek és a szülők eltérő digitális kompetenciával rendelkeznek, ezért lehetőséget kell biztosítani az eszközök közös kipróbálására annak érdekében, hogy önállóan is tudják alkalmazni a platformokat a tanulás folyamatában. A kezdeti nehézségeket ki lehet küszöbölni azzal, ha egy mindenki számára ismert és elérhető, felületet választunk, amely alkalmas a szinkron és aszinkron kapcsolattartásra, kommunikációra, oktatásra, feladatok és megoldások küldésére, ellenőrzésére, számonkérésre. Az a cél, hogy egy felületen könnyen elérhető legyen minden funkció, mert nehézséget okozhat a különböző platformok váltogatása.

A pedagógus is magánember, szülő, és másik osztályokba járó gyermekek pedagógusa is, ezért nem várhatjuk el tőle, hogy éjjel-nappal elérhető legyen a digitális iskolában. Megkönnyíti a tanulás folyamatát az időbeli határok előzetes meghúzása, és a szerepek egyeztetése. A tanítónak a legfontosabb feladata a tanítási időben a gyermekekkel történő foglalkozás, ezt a szülőknek is tiszteletben kell tartania. A konfliktusok megelőzésének érdekében előre meg lehet adni, hogy mikor van rendszeresen közös tájékoztató a mindenkit érintő kérdésekkel kapcsolatosan, illetve meg lehet egyezni abban, hogy mikor van lehetőség egyéni konzultáció kérésére, és mi a módja a valóban sürgős probléma elintézésének.

A szülők támogatása szükséges a gyerekek számára, de nagyon fontos, hogy a tanulóknak is szükségük van privát szférájuk megtartására. A napirend rendszeresen tartalmazhat olyan időszakot, amikor a pedagógus a szülő nélkül tud beszélni, együtt dolgozni a gyerekekkel, de nem szabad megfeledkezni a barátokkal a virtuális térben töltött idő jelentőségéről sem.

Fontos, hogy a szülők megértsék, és megerősítsük őket abban, hogy a gyermeküknek az a legfontosabb, hogy érzelmi biztonságot nyújtó, szerető szülők maradjanak a digitális iskola idején is. Szeressék gyermeküket, neveljék következetesen, megfelelő korlátokkal. Vezessék rá, majd erősítsék meg a jó úton, dicsérjék minél többet, hogy lelkes, boldog és ne szorongó gyermek legyen. Fontos, hogy a szülő nem tanár-tanító, hanem a pedagógus irányítása nyomán a gyermek segítője, aki úgy tudja támogatni gyermekét a tanulásban, ha az életkori sajátosságoknak megfelelő módszereket alkalmaz.

A szülőknek ehhez azonban segítség szükséges, hiszen nem tanulták a „pedagógus mesterséget”. Számukra részletes segédlet elkészítésére van szükség, amely tartalmazza, hogy mikor, miben és hogyan segítsenek gyermeküknek. Megoldókulcsra is szükség van, amely tartalmazza a helyes megoldási folyamatot, valamint a végeredményeket egyaránt azért, hogy ne érezzék kudarcnak, ha a gyermekük előtt nem tudják megoldani a feladatot. 
A szülők örülnek, ha meghatározott időközönként lehetőséget biztosítunk a tapasztalatcserére, amikor megoszthatják élményeiket, és megvitathatják nehézségeiket. A szülő számára is nagyon fontos a dicséret és a megerősítés, hogy az esetleges bizonytalanságát eloszlassuk és a motivációját is erősítsük sikerélményekkel.

Fontos, hogy az iskolás gyermek szülője nem a gyermeke helyett tanul, nem neki kell megoldania a feladatokat. Többet segít azzal, ha motivál, lelkesít, és megbeszéli a gyermekkel a tanulás menetét, segítséget nyújt az ütemezésben. Azzal is támogatja a gyermeket, ha a tanulás során néha rápillant, a feladat befejezését követően a tanultakat meghallgatja, a megoldások ellenőrzését segíti. Fontos, hogy ne csak tanulásról szóljon a digitális iskola, hanem a szülő a gyermek pihenő társa is legyen, mivel a közös játék élményt nyújt a szünetekben és a szabadidőben egyaránt.

\section{Összegzés}

Összességében elmondható, hogy a szülők megítélése szerint a gyerekek sikeresen teljesítették a számukra kitűzött feladatokat a tantermen kívüli oktatás idején, annak ellenére, hogy a vészhelyzet előtt a kisiskolások $74 \%$-a egyáltalán nem használt digitális eszközt a tanulás során. A tantermen kívüli online oktatás hatékonyságának növelése érdekében azonban fejleszteni kell a tanulók, a szülők és a pedagógusok digitális kompetenciáját, valamint ki kell dolgozni az online tanítás-tanulás módszertanát a megváltozott szerepek figyelembe vételével.

A pedagógusok rendelkeznek a megfelelő eszközökkel, a tantárgyak azonban nem minden esetben oktathatók személyes jelenlét nélkül. Malatyinszki Szilárd szerint (2020) a megoldást egy olyan, mindegyik fél által ismert platform jelentené, amely egyszerűen használható és integrálja az online felületek legfontosabb lehetőségeit. Úgy véljük, hogy vannak már ilyen felületek, Google Classroom és Meet, Discord és a Krétának erre kifejlesztett felülete, a Digitális Kollaborációs Tér (DKT), ahol minden rendelkezésünkre áll a tanítás-tanulás folyamatához, de természetesen lehet bővíteni a funkciókat, annak érdekében, hogy minél több élményt tudjon nyújtani a gyermekeknek a tanulás. Nagyon fontos azonban, hogy az eszközök használatára, és az online tanulás módjára mindenkit fel kell készíteni, és a digitális oktatás módszertanát az eddigi tapasztalatok alapján ki kell dolgozni.

A karanténiskola arra is felhívja a köznevelés figyelmét, hogy már első osztálytól be kell vezetni a tanulókat a digitális eszközök tanulás céljából történő alkalmazásának a rejtelmeibe. Mindenkinek az a vágya, hogy minél előbb viszszatérhessen újból a tantermi oktatáshoz, de nem szabad megfeledkezni arról sem, hogy karanténiskolában sok olyan új módszer is bevezetésre került, amelyeket a személyes jelenléttel történő oktatásban is célszerü lenne megtartani. Például a jelenléti oktatás idején is lehet alkalmazni az online felületeket az otthoni feladatok kiadására és visszaküldésére. Nagyobb teret lehet adni az 
önálló ismeretszerzésnek, szabad utat hagyni a tanulóknak a problémamegoldási utak önálló feltárására. Több önálló feladatot lehet adni a gyerekeknek, amelyeket nem a napköziben kell közösen megoldani,, hanem egyedül és online vissza lehet küldeni. Önálló csoportmunka esetében az online felületen keresztül együtt lehet dolgozni akár földrajzilag távol élő tanulókkal. Sok új platform kipróbálásra került, Linoit, Worwall, MindMup, Kahoot és különböző blogokat, podcastokat készítő felületek, amelyek lehetővé teszik a kreatív alkotást, segíti a tanulók önálló alkotását és otthoni tanulását.

Nem szabad megfeledkezni a hátrányos helyzetű tanulókról sem, akiknek sem eszközük, sem segítőjük nincsen. A jelenlegi kutatás is rávilágított arra, hogy a szülők iskolai végzettsége befolyásolja a tanulás hatékonyságát és a feladatok megoldásának sikerességét. A kedvezőtlen szociokulturális helyzettel rendelkező tanulók számára biztosítani kell a tanuláshoz szükséges digitális eszközök használatát, meg kell tanítani az eszközök alkalmazását és tanulástámogató segítséget is kell nyújtani számukra annak érdekében, hogy a digitális oktatással kiegészített osztálytermi tanulás során (is) egyenlő esélyekkel indulhassanak.

\section{Irodalom}

Benedek, A. (2013). Digitális pedagógia 2.0. Typotex Kiadó.

Bereczki, E. O. (2019). A kreativitás fejlesztése digitális eszközökkel támogatott tanulási környezetben: Mit üzennek a kutatások az osztályterem számára és mikor hallgatnak? Iskolakultúra, 29(4-5), 50-70. https://doi.org/10.14232/ ISKKULT.2019.4-5.50

Bíró, Gy. (2020). A hazai digitális távoktatás tapasztalatai a COVID-19-es járványhelyzet időszakában egy kvalitatív felmérés tükrében. In Kozma, G. (Ed), Fejezetek a COVID-19-es távoktatás digitális tapasztalataiból (pp. 18-41.) Gerhardus Kiadó. https://gfe.hu/wp-content/uploads/2020/07/covid-kotet-k5. pdf (2021.08.28)

Brom, C., lukavsky, J., Greger, D., Hanemann, T., Strakova, J. \& Savricek,R. (2020). Mandatory Home Education During the COVID-19 Lockdown in the Czech Republic: A Rapid Survey of 1st-9th Graders' Parents. Frontiers in Education, 103(5), https://doi.org/10.3389/feduc.2020.00103

Buda, A. (2017). Pedagógusok az információs társadalomban. IKT és OKTATÁS. Együtt vagy egymás mellett? Belvedere Meridionale Kiadó.

Cakin, M. \& Kulekci Akyavuz, E. (2021). Educational adventure of students in the COVID-19 period in Turkey: Determination of parents' views. International Journal on Social and Education Sciences (IJonSES), 3(1), 109-125. https://doi. org/10.46328/ijonses.87

Chuanmei, D., Cao, S. \& Li, H. (2020). Young children's online learning during COVID-19 pandemic: Chinese parents' beliefs and attitudes.Children and Youth Services Review, 118. https://doi.org/10.1016/J.CHILDYOUTH.2020.105440 
Csépe, V., \& Török, Á. (2020). Az okoseszközök használata kognitív idegtudományi nézőpontból. Gyermeknevelés Tudományos Folyóirat, 8(2), 133-145. https://doi. org/10.31074/gyntf.2020.2.133.145

Engler, Á. (2020). Távolléti oktatás a családok szemszögéből. Civil Szemle, Különkiadás 117-132. http://epa.oszk.hu/04100/04123/00005/pdf/EPA04123_ civil_szemle_2020_ksz_117-132.pdfht (2021.04.29)

Engler, Á., Markos, V. \& Dusa, Á. R. (2021). Szülői segítségnyújtás a jelenléti és távolléti oktatás idején. Educatio, 30(1), 72-87. https://doi.org/10.1556/2063.30.2021.1.6

Fekete, M. (2020). Digitális átálás - az első hét tapasztalatai. Iskolakultúra, 30(9), 77-95. https://doi.org/10.14232/ISKKULT.2020.9.77

Forgó, S. \& Komló, Cs. (2015). Blended learning, tudásszervezés, hálózatalapú tudásmegosztás. Eszterházy Károly Főiskola. http://p2014-25.palyazat.ektf.hu/ public/uploads/6-blended-learning-tudasszervezes-halozatalapu-tudasmegosztasforgo-sandor-komlo-csaba-isbn_565d55661de45.pdf (2021.02. 21.)

Grover, S., Goyal, S. K., Mehra, A., Sahoo, S. \& Goyal, S. (2021) . A Survey of Parents of Children Attending the Online Classes During the Ongoing COVID-19 Pandemic. The Indian Journal of Pediatrics, 88(3), https://doi.org/10.1007/ s12098-020-03523-5

Hargitai, D. M., Sasné Grósz, A. \& Veres, Z. (2020). Hagyományos és online tanulási preferenciák a felsőoktatásban - A Covid-járvány kihívásai. Statisztikai Szemle, 98(7) 839-857. https://www.ksh.hu/statszemle_archive/ all/2020/2020_07/2020_07_839.pdf (2021.08.28)

Jakab, Gy. (2020). Digitális környezetismeret. Taní-tani Online, 08.16. http://www. tani-tani.info/digitalis_kornyezetismeret (2021.02.03.)

Lénárd, A. (2019). A digitális környezet következményei és lehetőségei kisgyermekkorban. Iskolakultúra, 29(4-5), 99-114. https://doi.org/10.14232/ ISKKULT.2019.4-5.99

B. Németh, M., Hódi, Á., Juhász, F., Sárik, A., \& Tóth, E. (2021). Szülők véleménye az óvodáskorú gyermekek IKT-eszköz használatának negatív és pozitív hatásairól. Gyermeknevelés Tudományos Folyóirat, 9(1), 8-38. https://doi. org/10.31074/gyntf.2021.1.8.38

Sárkány, K. (2019). Digitális oktatási tér. Új Köznevelés, 5(3-4), https://folyoiratok. oh.gov.hu/uj-kozneveles/digitalis-oktatasi-ter (2020.12.19.)

Malatyinszki, Sz. (2020). A digitális oktatás megélése. http:/doi.org/10.13140/ RG.2.2.36400.38408

Papp-Danka, A. (2011). Az online tanulási környezet fogalmának értelmezési lehetőségei. Oktatás-Informatika, 3(1-2), 43. http://www.oktatas-informatika. $\mathrm{hu} / 2011 / 12 /$ papp-danka-adrienn-az-online-tanulasi-kornyezet-fogalmanakertelmezesi-lehetosegei/ (2021.01.12.)

Papp-Danka, A. (2014). Az online tanulási környezettel támogatott oktatási formák tanulásmódszertanának vizsgálata. ELTE Eötvös Kiadó. 
Páli, A. (2021). Digitális oktatás során alkalmazott módszerek bemutatása. Szakdolgozat. MATE Neveléstudományi Intézet.

Racskó, R. (2017). Digitális átállás az oktatásban. Gondolat Kiadó.

Simonson, M., Zvacek, S. M. \& Smaldino, S. (2019). Teaching and Learning at a Distance: Foundations of Distance Education. Information Age Publishing.

Szilveszter, Á., Kassai, R., Takács, Zs. \& Futó, J. (2021). Az otthoni tanulás sikerességét bejósló tényezők a Covid-19 okozta vészhelyzet miatt kialakított digitális munkarendben eltérő szocioökonómiai helyzetű családok esetében. Educatio, 30(1), 88-102. https://doi.org/10.1556/2063.30.2021.1.7

Turzó-Sovák, N. (2020). Pedagógushallgatók digitális kompetenciáinak fejlesztési lehetőségei. Gyermeknevelés Tudományos Folyóirat, 8(2), 164-173. https://doi. org/10.31074/gyntf.2020.2.164.173

Thékes, I. (2020). A COVID-19 vírusjárvány miatti hazai távoktatás digitális megoldásainak elemzése. In Kozma, G. (2020, Eds.), Fejezetek a COVID-19-es távoktatás digitális tapasztalataiból (pp. 7-18.) Gerhardus Kiadó. 


\section{Benczémé Fekete, A.}

\section{Digital education from the perspective of the family}

Overnight the Covid-19 pandemic completely altered our lives as well transforming the daily schedules of schools. Teachers needed to shift rapidly to dig0ital education, while at the same time, numerous forums were initiated to provide technical help for each other and gathered the tools and applications available. Parents, too, faced new challenges, since they also had to acquire new skills in order to meet the new requirements of the schools. In this non-representative research the goal was to examine how the parents of lower grade students $(\mathrm{N}=113)$ managed to adapt to the role of a pedagogue all of a sudden, in their home environments. The research focused on the initial period of digital education from the perspective of the parents. We examined the tools and applications utilized during the era of online education. The forms of pedagogue-student-parent communication were introduced, as well as the means of coordinating the educational process. The research also examined how the daily schedules of the students were created and what new ways of spending their free time arose. With the help of the research we can gain an insight into the months of digital education from the parents' perspective. Generally, it was be concluded that parents and children met the requirements of the online period successfully.

Keywords: digital education outside classroms, parental roles, digital competences 